\title{
Learning Problems in Basic Japanese Language Writing Course: An Analysis of Language Errors
}

\author{
Didik Nurhadi \\ Universitas Negeri Surabaya \\ Surabaya, Indonesia \\ didiknurhadi@unesa.ac.id \\ Retnani \\ Universitas Negeri Surabaya \\ Surabaya, Indonesia \\ retnani@unesa.ac.id
}

\author{
Masilva Raynox Mael \\ Universitas Negeri Surabaya \\ Surabaya, Indonesia \\ masilvamael@unesa.ac.id \\ Mintarsih \\ Universitas Negeri Surabaya \\ Surabaya, Indonesia \\ mintarsih@unesa.ac.id
}

\begin{abstract}
This paper aims to describe the language errors that found in essays made by university freshmen who take Japanese program in Universitas Negeri Surabaya (UNESA). The course of making essay in Japanese Language Learning becomes a benchmark to see students' writing skill in Japanese Language. The goal of this analysis is to emphasize the description of the forms of Japanese language errors and their classification. The data was analyzed by using descriptive analysis method. Results revealed that the forms of language errors in essays made by students could be categorized into two kinds. They were grammatical and discourse errors. The description about the classification of the error forms is expected to be beneficial in helping teachers or learners of Japanese language in order to pay more attention to the factors that can cause the errors appeared. In conclusion, this paper is hoped to be useful in minimalizing the language errors in Japanese language used.
\end{abstract}

Keywords-language error; Japanese language; learning problems

\section{INTRODUCTION}

Research on communication skill, especially writing in Japanese language of foreign learners have been analyzed by many experts. They concluded that there is a need of improvement on learners' writing skills in Japanese, especially the need to minimalize language errors in writing by improving the quality of writing course itself [1][2][3][4]. Tashiro [1] argued that Japanese learners, intermediate and upper level, have difficulties in expressing their language because they do not have enough knowledge on grammmar and vocabularies of Japanese. He took the subjects of his reserach from China and Korea in order to investigate the factors contributing to the essays made by the learners which are found to be difficult to understand by the natives [2].

Tashiro [1] also concluded that the ability of the learners from both countries in using the right grammar and dictions is quiet low, especially when the context is broad, it makes the essays very difficult to understand. Tashiro [1] also confirmed that the factors contributing to the difficulty of essays made by students had various things, aside from the knowledge of text structure and text composition. This problem cannot be separated from the notion that writing is a complex process in language learning that connect to other skills such as vocabulary enrichment, grammatical rules, and a skill to organize idea in order to gain suitable topic for completing the essays.

Learning problems in writing Japanese essay, especially related to the problems of expressing learners' minds and idea, is the greater area that researchers focus on. It is because many researchers did not pay attention on it, especially in Indonesian context. However, there are many research about sakubun done focusing on the factors contributing to the difficulties of understanding Japanese essays in Chinese and Korean contexts [1][2].

A literature study on similar research had been done. There are a lot of similar research conducted similarly. But almost all of them involve the participants that are currently learning Japanese in Japan with much ease and much opportunity to improve themselves. Meanwhile, research that take the participants out of Japan were not frequently done. This contrast was predicted to be the result of the differences happened between Japanese language learners that study in Japan and in outside Japan. Therefore, this study will examine the course of 'sakubun' with the participants from students of Japanese education program in UNESA. Through this research, it is hoped that the problems found in students' essays can be a comprehensible view about text form the view of linguistics and language errors.

The phenomenon of language errors in second language learning, especially for foreign language learners, including Japanese cannot be denied. Research on language errors 'goyou bunseki' foreign language learners in Japanese have been done in several point of views. As an example, a research by Kanai [6] with the subject of Chinese and Korean students that learn Japanese in understanding referent word so and $a$ from a point of view by 'Kyоuуuи Chishiki'. From that research, it can be seen that both learners have difficulties in the use of those referent words. They also tended to mismatch them. Then, Kanai tried to solve the problem by conducting a certain treatment in a form of lesson to explain more about those two words. Based on the questionnaires, result showed that the inability of students in understanding tose words can cause the use of the words that is based on their mother tongue. 
However, there is a few research on Japanese language errors done in Indonesian context. Thus, this paper seeks to find the real problem about the essays made by students. Therefore, results of this research are expected to be a good input in order to improve the teaching and learning process if writing course in Japanese language learning.

\section{METHOD}

\section{A.Participants}

There were 28 students of Japanese Education Program who take 'sakubun' course participated in this research. They were assigned to make 6 essays with 6 topics for each student. The total essays gathered were 168 . The topics of the essays were self-introduction, place to stay, hometown, idol, mystery, and holiday. The errors found in the essays would be gathered as a database and be coded. Then, there would be a process of reduction based on the triangulation theory and the assistance of native speaker.

\section{B.Method}

The gathered data were the forms of language errors in essays made by students of Japanese Education Program. They were analyzed using descriptive method. Those forms then were decribed and classified. The classification system was based on Harasawa [7] with a little modification. It is done in order to understand the forms of errors in essays made by students of Japanese Education Program in UNESA. Below are the classification of the errors:

\section{Grammatical Errors}

a. Errors in Conjugation

b. Errors in Word Choices

c. Errors in Auxiliary Words

\section{Discourse Errors}

\section{a. Errors in Conjunction}

b. Errors in Referent Words

c. Errors in Word Meaning

The analysis of language errors had been concluded by Nagatomo [8]. Considering the importance of this analysis, the benchmark in determining the suitability of language used is through two point of views. They are the syntactic and discouse suitabilities.

\section{RESULTS AND DISCUSSION}

A. Results

a. Language Errors

1.) Errors on Sentence Structure

Errors in Japanese sentence structures in students' essays were found vary. The findings of this research will be explained in the following subtopics and given some examples of the error forms.

\section{2.) Errors in Conjugation}

In this classification, there were errors in conjugation of verbs and nouns, errors in spelling of kanji, hiragana, katakana, and also the errors in the presents of okurigana in kanji with
Japanese pronunciation (wago). The results of the classification can be found as follows.

TABLE I. LANGUAGE ERRORS

\begin{tabular}{|l|l|}
\hline Kinds of Errors & Frequency \\
\hline Grammatical & 126 \\
\hline a. Conjugation & 82 \\
\hline b. Word Choices & 180 \\
\hline c. Auxiliary words & \\
\hline Discourse & 2 \\
\hline a. Conjunction & 6 \\
\hline b. Referent Words & 10 \\
\hline c. Word meaning & \\
\hline
\end{tabular}

Results of the analysis process in students' essays can be categorized into two. They are grammatical and discourse errors. There are three groups of errors in grammar aspect. They are errors in conjunction, errors in word choices, and errors in auxiliary words. Moreover, there are also three groups of errors in discourse aspect. They are errors in conjunction, errors in referent words, and errors in word meaning.

The kinds and frequencies of errors in students' essays can be seen in table 1. It showed that the grammatical errors found are frequently happen. This group of grammatical errors, which are conjunction, word choices, and auxiliary words become a serious problem and should receive more attention in Japanese language learning. These kinds of basic errors should be minimalized by giving the learners more explanation and exercised on the use of conjunction, word choices, and auxiliary words. This problem cannot be solved by only having two or three times exercising. It is a really big problem. It frequently happens in every Japanese language learning. Japanese language teacher is hoped to be aware of this problem so that the basic errors such as conjunction and word choices can be decreased.

Below are the explanation and some examples of error forms found in students' essays:

1) a. Ji ga yomiyasuide, suto-ri mo ii to omoimasu.
b. Ji ga yomiyasukute, suto-ri-mo ii to omoimasu.

(The letters are easy to read and the story is good)

In sentence 1a, there is an error on the spelling of a word (hyouki) and suto-ri, that should be written in suto-ri- which means the sound of to and $r i$ are same in their length. (chouon) because that word is adapted from English 'story', there is also an error on adjective I (i-keiyoushi) on the word yasui which is given auxiliary $d e$ in order to connect the predicate with the next sentence. Errors in conjugation like in sentence 1a is defined as the errors in conjugation of verbs and nouns. In Japanese learning, Joshi de is used as conjugation for adjective na (nakeiyoushi) when it is used to connect one predicate to others in compound sentences. This also applicable in the change of adjective I (i-keiyoushi) with the conjugation de. In fact, 
conjunction for adjective I (i-keiyoushi) should be changed first into -te, for instance, adjective takai becomes takakute, yasui becomes yasukute.

Errors made by students were not too many. But in fact, the misspelling in both hiragana and katakana were frequently found in students' essays. The errors in spelling (hyouki), especially the conjunction should be decreased to omit in essays since they are categorized as basic errors in producing essay.

2) a. Watashi wa kyoumi deshita.

b. Watashi wa kyoumi o mochimashita.

3) a. Tomodachi kara waruguchi o morau noni watashitahi wa gaman ni narimasu.

b. Tomodachi ni waruguchi o iwaretemo watashitachi wa gaman shimasu.

In a case of language errors in sentence $2 \mathrm{a}$ and $3 \mathrm{a}$, they were different with the errors happened in 1a that had been mentioned. Sentence $2 a$ and $3 a$ were happened because of the lack of knowledge on expressing a certain condition. It was also happened because the predicative form in sentence 2 a could not explain the topic sentence. The actual model of the sentence was meishibun 'a sentence with a noun as its predicate', but the noun used to fill the predicate position was not suitable in Japanese language.

Language error as seen in sentence 3a, based on experts, was caused because of the interference happened with students' way of thinking and their mother tongue. The expression waruguchi 'innuendo' in Japanese, should use a special verb that is permanent. Furthermore, this kind of verb cannot be replaced by other forms. This kind of expression is in the same position with the other forms such as idioms, proverbs, and other. The form waruguchi 'innuendo' only uses the verb 'iu' to show someone's activity in saying something bad or an innuendo to others. This kind of knowledge is usually neglected or unknown to students in early stage.

Another thing to consider is that the errors related to the use of verbs that had become a special thing to pay more attention in Japanese as a foreign language learning. This kind of errors can be categorized as an intermediate error since it happens on the verbs and conjunction used. Therefore, this kind of error, as they were more than one error happened, could affect the entire sentence in its meaning.

4) a. Jovan san wa itsumo Keiza san o meiwaku shimashita.

b Jovan san wa itsumo Keiza san ni meiwaku o kakemasu.

5) a. Soshite, takusan seimei no chishiki ga moratte kuremasu.

b. Soshite, seimei ni tsuite no chishiki ga arimasu.

Sentences $4 \mathrm{a}$ and $5 \mathrm{a}$ were the examples of errors in verbs used. The knowledge on verb usage was not maximum. These problems had become a serious matter since the beginning of Japanese language learning, especially Indonesian learners. As seen in sentence $4 \mathrm{a}$, it should use $n i$ as the indirect object as the ones who got the effect or result from the act done by the verb. Students used o that was functioned as the one who got the effect. In sentence 4a, students also made an error especially the use of noun meiwaku 'disturbance' along with suru as a mark for the change to be a verb. In fact, in Japanese learning, a noun meiwaku should be used along with a special word that is kakeru so that the expression will be meiwaku o kakeru 'disturb'. This verb needed an element as the one who got the effect or result which is marked by the word $n i$.

It can also be seen in sentence $5 \mathrm{a}$, which classified into errors in conjunction of verbs. Verb-te moraimau (accepting the product of activity in which the verb is shown ) and another similar form cannot be grouped with the verbs that means giving and taking. Therefore, form of moratte kuremasu in example 5 follows this rule.

\section{3.) Errors in Word Choices}

Error forms in the third rank based on the analysis is the word choices. It is natural and broadly used in Japanese communication. Below are the examples found in the data.

6) a. Takusan no shiken ga, kanojo wa seikatsu no tame ni akiramenai no desu.

b. Mondai ga takusan attemo, kanojo wa seikatsu no tame ni akiramenai no desu.

7) a. Sore de, watashi mo sou desu.

b. Sore de, watashi mo sou omoimasu.

8) a. Dakara, raku ni onomatope o benkyoushimashou.

b. Dakara, tanoshiku giongo, gitaigo o benkyou shimashou.

Errors in sentence $6 \mathrm{a}, 7 \mathrm{a}$, and $8 \mathrm{a}$ were classified as the errors in word choices as they used inappropriate terms in Japanese grammar. In sentence $6 \mathrm{a}$, the error occurred was not from the grammatical aspect but rather from the choice of words that was not appropriate and unnatural in Japanese. This kind of knowledge needs to be understood through an intensive exercises. More reading and writing in Japanese was the main key for students in order to improve their ability in making essays that are comprehensible. Meanwhile, in sentence $7 \mathrm{a}$ and $8 \mathrm{a}$, there were unsuitable usage of words appeared. Students may lack of the vocabularies in expressing their ideas so that they translated a certain word into another language to cover the inability.

\section{4.) Errors in the Use of Auxiliary Words}

Most errors were found in the use of auxiliary words. Auxiliary word in Japanese is called joshi. The ability to master joshi becomes one of the indicator of Japanese language learning success. It is not a secret that the mastery of joshi is becoming one of the points in filling the instruments of completion tests. Considering the importance of this auxiliary words, it is frequently discussed in Japanese course and became a problem in Japanese education program. Here are the examples of the unsuitable use of auxiliary words.

9) a. Nihon dewa shiki ga ate, kisetsu no naka de iroirona matsuri ga arimasu.

b. Nihon niwa shiki ga ate, kisetsu no naka de iroiro na matsuri ga arimasu. 
10) a. Sakura o saku nowa 3gatsu kara 4gatsu dake kirei desu.

b. Sakura no saku nowa 3gatsu kara 4 gatsu made dake de kirei desu.

11) a Ima watashi wa mou 2nen ni benkyou shiteimasu.

b. Ima watashi wa mou 2nen de benkyou shiteimasu.

Errors in 9a, 10a, and 11a above are the examples of the errors in the use of auxiliary dewa which should be niwa since it related to the linearity of the verbs used. In sentence 9a, the predicative word was verb arimasu 'there is' which showed the existence of the object mentioned. The function of adverb of place here was filled with auxiliary $n i$. Students chose to use $d e$, meanwhile the knowledge of $n i$ and $d e$ had been taught since for the very beginning.

It is also happened in sentence $10 \mathrm{a}$ and $11 \mathrm{a}$, there are basic errors in the use of auxiliary words or the absence of them. Each errors implies on the unsuitability of grammar rules in Japanese language, that causes the inability of native speakers in understanding the essays, the presence of bias, and the rejection of grammatical rules.

c. Errors in Discourse

1.) Errors in Conjunction

12) a. Mata wa, kono shousetsu no hanashi wa wakariyasui desu.

b. Sono tame, kono shousetsu no hanashi wa wakariyasui desu.

13) a. Soshite, koukou no toki ii nihongo no sensei ga imashita. Soshite oshiekata ga omoshirokute tanoshikatta node watashi wa nihongo no sensei ni naritai desu.

b. Soshite, koukou no toki ii nihongo no sensei ga imashita. Oshiekata ga omoshirokute tanoshikatta node watashi wa nihongo no sensei ni naritai desu.

In sentences $12 \mathrm{a}$ and $13 \mathrm{a}$, unsuitable use of conjunction was appeared. Matawa is a conjunction to say an opposite question (usually in a form of choice) with the previous question. In fact, sentence 12 a was meant to connect a cause-effect statement, especially to show that the part was the one who got the effect from a certain cause.

Meanwhile sentence 13a, errors found in the overuse of conjunction soshite in two sentences that are in a sequence. The use of this conjunction is not making the discourse clearer. Instead, it makes the texts not natural and effective. The omitting of soshite in the second sentence will not change the meaning and it is accepted in Japanese grammatical rules. The practicality of conjunction usage becomes an important thing in discourse matter.

\section{6.) Errors in Referent Words}

14) a. Doubutsu to Ueki ga nakunarihajimete, kanashii suto-ri-ga afuremasu. Ano jidai ni ikiteiru noba wa chikyuu no joutai ni taishite shinpai o kanjiteimasu.

b. Doubutsu to Ueki ga nakunarihajimete, kanashii suto-ri-ga afuremasu. Sono jidai ni ikiteiru noba wa chikyu no joutai ni taishite shinpai desu.
15) a. ...jikan o shiyoushite yoku oshieraremasu. Sore wa watashi ga nihonjin ni kanshin suru youni narimashita.

b. ...jikan no tsukaikata o oshieraremasu. Sonokoto o shitte, watashi wa nihonjin ni kanshin suru youni narimashita.

In the sentences above, an error of referent words occurred in discourse aspect. In sentence 1, referent word ano jidai is categorized as an error since it should use sono jidai instead. Students' understanding on the use of referent words or referent is still becoming a problem. There is also a problem of Japanese language learning. There are many expressions that have the same meaning but different usage. A comprehensive understanding is needed to the kinds of expression. One of the difficulty factors faces by Japanese language learners is because of this factor.

For instance, the use of referent in Japanese can be categorized into three. The errors in the use of referent word as seen in example 1, related to the discourse, became more complicated since it connects to the concept of kyoyuu chishiki kenri 'the rights of the same. In the context of sentence 1, the rights holder of the knowledge or the topic was in the hands the writers. Readers or listeners did not have such knowledge of it. In this situation, referent ano was not accepted since it is used to show the knowledge that had been known together and referred to the objects out of the topic that is abstract. The knowledge of the function of referent words was not maximally taught so that students still have the difficulties in interpreting the sentence. Then, the lack of knowledge in the use of referent also made students to translate word by word to Japanese.

\section{7.) Errors in Word Meaning}

Errors in word meaning can be categorized as a large scale errors because related to the sentence produced whether it is comprehensible or not to the native speakers. Some cases in this form of errors is related to the use of expression in Japanese. There is a questionable meaning in every sentence made by students below. Therefore, the researchers try to insert a certain expression to make the sentences easy to understand.

16) a. Ichinichi ni Kuinisan no sai wa Inen ni fuemashita.

b. Ichinichi ni (?) Kuinisan no nenrei (?) wa 1 nen ni narimashita.

17) a. Sono shousetsu no omoshiroi koto wa Rekosan no koi de, Kuinisan no sagashidori okimashita.

b. Sono shousetsu no omoshiroi koto wa Rekosan no koi no koto desu. (??)

18) a. Soshite, jissei no dorobou ga mitsukemashita. Dorobou wa tomodachi no waruguchi deshita.

\section{b. Soshite, jissai no dorobou ga mitsukeraremashita.}

Dorobo wa tomodachi ga utagatte iru hito deshita.

19) a. Aru hi charurii wa onna no kenkyuu ni aemashita.

b. Aru hi charurii wa kenkyuu shiteiru (?) onnna no hito (?) ni aemashita. 


\section{B. Discussion}

The results from the identification of text characteristics in students' essays of sakubun course as seen in subtopic A has several important points to be discussed, especially to look for the characteristics of text construction.

The use of conjunction in students' essays in table 1 showed that there is a various usage of conjunctions. On the other hand, results also indicate that the variation of conjunctions showed the similarity of kinds of conjunction used by the students. It means that students frequently use the same conjunction and the usage of it focuses on the certain conjunctions. The use of conjunction 'tenkagata' in students' essay had been a highlight along with the rest conjunctions.

Many reasons available behind the use of this conjunction including students' knowledge from the very beginning. Student had known the conjunction soshite 'then,next' earlier [9]. They frequently used it in written and spoken communication. But, the overuse of it had been a problem in Japanese learning. It decreased the natural of Japanese communication skill. This was in contrast to the original Japanese text which not use that particular words often. The presence of a conjunction in a certain space is to function the discourse of the text. Such as the use of conjunction junsetsugata 'cause-effect, gyakusetsugata 'a contrast' becomes important to highlight some parts in order to be the main information for the readers.

Related to the appearance frequency of the conjunction in the text, there are many research that analyzed the presence of conjunctions in Japanese text and found that not many of conjunctions were appeared in some particular part in a text. Based on this understanding, the presence of conjunction in students' essays is too monotonous and ineffective. Researching the form of conjunction 'soshite' as the most used conjunction in students' essays, in fact this conjunction can be omitted 'shouryaku' and used in the text.

The results of errors investigation in students' essays can be categorized at a higher amount. Errors in grammatical aspect becomes the first rank in this research. The basic errors in Japanese communication can be decreased by giving more explanation and exercises about conjugation, auxiliary words, and word choices. This kind of problem is not easy to be solved in two or three times exercises. This particular problem frequently occurs in Japanese language learning. Teachers or lecturers of Japanese education program should be aware of this problem so that the basic errors such as conjunction and word choices can be decreased [10].

\section{CONCLUSION}

Results confirmed that errors found in essays made by university freshmen in writing course were various. The classified errors in this paper are expected to be a great input in writing course of 'sakubun' in order to be better. These errors are also expected to be a main consideration for teachers or lecturers to improve the learning activity that is able to minimalize the errors appeared in Japanese language learning.

\section{REFERENCES}

[1] H. Tashiro, "Nihongo Gakushuusha no Sutori Setsumeibun no Mondaiten -Wakarinikusa to Iu Kanten kara -," Gengo Bunka to, vol. 13, 2005 .

[2] H. Tashiro, "Nihongo Gakushuusha no Bunshou no Wakarinikusa ni Kansuru Jissho Kenkyuu -Sutori Setsumeibun to Ikenbun no Baai -," Gengo Bunka to Nihongo Kyouiku, vol. 32, 2006.

[3] Tsuchida and M. Imai, "Ryugakusei ni Taisuru Koukateki na Akademic Writing no Shidouhou Oyobi Kyouzaikaihatsu no Tame no Kisokenkyuu," Oubirin Daigaku Gengo Kyouiku Rongyou, 2007.

[4] Tsubone, Yutari dan Tanaka Mari. Exploring "Good Content" and "Good Organization" in the Assessment of Essay Shin Japanese as Second Language: Commonalities and Differences in Assessment Perspective. Shakai Gengokagaku. Vol. 18. No. 1, pp. 111-127. 2015.

[5] Tsubone, Yutari. "The analysis of Japanese Essays by Chinese Learners who have undergone preliminary Japanese education for 9 months: Focusing on Organization and Cohesion of Essays". Journal of Osaka University of Tourism. Vol.19, no.-, pp. 9-20, 2019.

[6] H. Kanai, "Kankokugowasha to Chuugokugowasha no Shijishi (so to A) no Goyou: Kyouyuu Chishiki towa Nanika Toiu Kanten kara," Saitama Daigaku Nihongo Kyouiku Kiyou, vol. 9, no. -, pp. 1-15, 2015.

[7] I. Harasawa, "Nihongo Shochuukyuu Gakushuusha no Sakubun Shidou: Gakushuusha no Goyou Bunseki wo Moto ni," Shizuoka Daiku Kokusai Kouryuu Sentaa Kiyou, vol. 6, no. -, pp. 1-15, 2012.

[8] K. Nagatomo and K. Semada, "Goyobunseki no Kisokenkyu (1)," Kyouikugaku Kenkyuu Kiyo, vol. 2, no. 33, pp. 144-149, 1998.

[9] Ishiguro, Kei. " Soshite o Shokyu de Dounyuusubeki ka" Gengo Bunka, vol. 37, no. -, pp. 27-38, 2000.

[10] Suzuki, Tomomi. "2000nendo Chukyu Sakubun ni Mirareru Goi Imi ni Kakawaru Goyo: Shochukyu Reberu ni Okeru Goi Imi Kyoiku no Juujitsu o Mezashite". Ryugakusei Nihongo Kyoiku Sentaa Ronshuu. Vol. 28. No:-. Pp. 27-42. 2002. 